\title{
DEVIANCT BEHAVIOR OF EMPLOYEES AND JOB PERFORMANCE - EVIDENCE FROM SELECTED AGRICULTURAL RESEARCH INSTITUTES IN NIGERIA
}

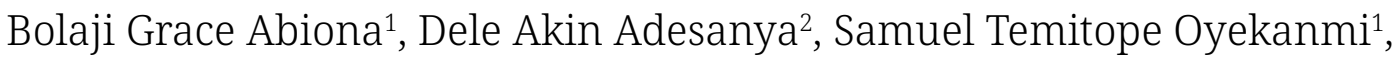 \\ Micheal Tunde Ajayi ${ }^{1}$ \\ ${ }^{1}$ Department of Agricultural Administration, Federal University of Agriculture, Abeokuta, P.M.B. 2240, Ogun State, \\ Nigeria \\ ${ }^{2}$ Department of Industrial Relation and Human Resource Management, Olabisi Onabanjo University, P.M.B 2020, \\ Ogun State, Nigeria
}

Link to this article: https://doi.org/10.11118/actaun.2021.021

Received: 28. 7. 2020, Accepted: 26. 2. 2021

To cite this article: ABIONA BOLAJI GRACE, ADESANYA DELE AKIN, OYEKANMI SAMUEL TEMITOPE, AJAYI MICHEAL TUNDE. 2021. Devianct Behavior of Employees and Job Performance - Evidence From Selected Agricultural Research Institutes in Nigeria. Acta Universitatis Agriculturae et Silviculturae Mendelianae Brunensis, 69(2): 241-249.

\begin{abstract}
This study determined the effects of workplace deviance on employees' job performance in selected Research Institutes in Oyo State, Nigeria. A multistage random sampling technique was used to sample two hundred and fifty five (255) respondents. Data were collected through a structured questionnaire and were analyzed using descriptive and inferential statistical tools. Results revealed that mean age of respondents was 36.9 years and that majority (53.7\%) of the respondents were male. The hierarchical regression analyses results indicated that overall job performance was significantly related to political deviance $\left(b_{1}=-2.015, p<0.05\right)$, personal deviance $\left(b_{1}=-2.531, p<0.05\right)$ and production deviance $\left(b_{1}=1.734, p<0.05\right)$ This study concluded that despite various forms of workplace deviance identified in the study area, employees still perform better in their respective job assigned to them but not up to the maximum level expected. Finally, the study recommended that measure should be put in place to tame this act in other to achieve organizational goals. It was however recommended that conducive work environment be put in place to reduce work deviant behaviors. So also, training and workshops for the employees, both local and international level that can enhance their performance should also be put in place to reduce work place deviance.
\end{abstract}

Keywords: workplace, deviance, employee, job performance, Agricultural Institute

\section{INTRODUCTION}

Organizations today are competing for space, image and survival especially in this ever dynamic world. It is on this premise that, organization are looking for committed and loyal employee who can perform and help to build the image of the organization (Uddin et al., 2013; Kart et al., 2018; Adeogun et al., 2019; Abiona et al., 2020). The image of any organization is a reflection of employee's commitment attitude and loyalty towards work (Aksu, 2016; Ng, 2017; Zheng et al., 2017). Managers in any organization are interested in achieving their 
targeted goals by reducing any form of workplace deviance as this may be a very disruptive and costly problem in terms of both physical and financial life of the employees (Ogunyemi, 2006; Sun and Wang, 2017; Friedman et al., 2018). Several studies confirmed that deviant behavior had brought huge negative impact on employees' productivity which leads to deterioration of employee's performance (Spector et al., 2006; Peng et al., 2011; Zheng et al., 2017). Workplace deviance had drawn the interest of many researchers and policy makers in most organization in recent years (Abiona et al., 2014; Katou, 2015; Sharma et al., 2016). Deviance can simply be put as a violation of the norm, values, rules and regulations of an organization. According to Robbin and Jugde (2007), workplace deviance is a habit exhibited consciously or unconsciously in unethical and unruly behaviours by employees in the course of work. Also, Aremu (2003); Kline (2011); Abdullah and Marican (2017) defined work place deviance as a voluntary behaviour that violates institutionalized norms and threatens the well-being of employees and organization itself. $\mathrm{Ng}$ (2017) established that, some employees who work in government agencies have the potential of carrying out this destructive behavior if not tamed. In most organization it has been established that workplace deviance is more prevalent among supporting staff because of their duties is less demanding (Griffin et al., quoted in Mazni and Rosiah, 2011; Jiang et al., 2017). Several behaviour is considered deviant when employees are nonconforming to an organisation's policies, core values, culture and such behaviour impede the vision, welfare and organisational standards (Bennett and Robinson, 2003; Robbins and Judge, 2007; Kottawtta, 2007; Schilzand et al., 2016; Jiang et al., 2017). More so, there are two types of workplace deviance and the two serve different purposes such as constructive deviance is a form of positive deviance by which employees engage in innovative behaviours that can bring about creativity (Mazni and Roziah, 2011 and Mekporand Dorty-Baah, 2017). The second type is destructive deviance which occur when employee intentionally wants to cause harm to the organization and the co-worker such as taking unauthorized work breaks, insulting audience, hitting or yelling at others, gossiping, undermining fellow employees and destroying organizational property. It could be said that, these aforementioned forms of workplace deviance affect not just the organization but the entire workforce at large in terms of their performance and satisfaction with the organization. Furthermore, for employee to perform to the extent of achieving organizational goals, workplace deviance attitude must be attached with penalty that will help to reduce any form of organizational deviance to tolerable level. The study addressed specifically the effects of workplace deviance on employees' job performance in selected
Agricultural Research Institutein Oyo State, Nigeria. The specific objectives of the study were to:

1. Identifying various forms of workplace deviance.

2. Determine employee's job performance.

3. Identify the challenges faced by the employees in the study area.

\section{MATERIALS AND METHODS}

The study was carried out in three selected agricultural research institutes in Oyo State, Southwest, and Nigeria. The research institutes were: Cocoa Research Institute of Nigeria, Forestry Research Institute (FRIN) Ibadan, Oyo State Nigeria and Ogun - Oshun River Basin Development Authority (OORBDA), Ogun State, Nigeria. The population of this study comprised of employees in the three selected Research Institutes, A multistage random sampling techniques was used to select the respondents form the study area. Out nine agricultural institute in Oyo state two (2) were randomly picked and out of two research institute in Ogun State one (1) was also picked resulting into 3 institutes. The research was carried out among 255 respondents. The data for the study were obtained using a structured questionnaire.

The questionnaire was structured into sections to generate information about personal characteristics such as age, sex, and income which serve as a control variables (Du et al., 2016). Workplace deviance was measured with DWB scale developed by Tusi et al. (1997); Rahman et al. (2012) adapted by Abiona et al. (2018). It was a 24 items scale carefully selected form Robinson and Beenelt (1995) and Appelaum et al. (2007) and were also rated using 5 points Likert typed rating scale of: Strongly agree $=5$, agree $=4$, undecided $=3$, disagree $=2$ and strongly disagree $=1$.

More so, employee's job performance was measured 9 items scale with Tsui et al. (1997) and further adapted by Abiona et al. (2018) using 5 points Likert typed rating scale of: Strongly agree $=5$, agree $=4$, undecided $=3$, disagree $=2$ and strongly disagree $=1$. Descriptive and inferential statistics were used for data analysis. Descriptive statistics included frequencies, percentages, mean and standard deviation. Regression analysis was used to determine the effects workplace deviance on employee's job performance.

\section{RESULTS AND DISCUSSION}

\section{Personal Characteristics of the Respondents}

Age is an important factor to be considered in a profit driven organization. The mean age of the respondents in the study area was 36.9\% years which means that respondents in the study area were young, energetic, full of life and active people who can perform well in their organization. The result agrees with the findings of FAO (1997); Abassi (2000); Isaac (2011); Abiona et al. (2020) who 
I: Distribution of the respondents by their personal characteristics $(n=255)$

\begin{tabular}{|c|c|c|c|}
\hline Variables & Frequency & Percentage & Mean \\
\hline \multicolumn{4}{|c|}{ Age group (years) } \\
\hline$<30$ & 65 & 25.5 & \\
\hline $31-35$ & 49 & 19.2 & 36.9 \\
\hline $36-40$ & 55 & 21.6 & \\
\hline $40-45$ & 46 & 18.0 & \\
\hline$>45$ & 40 & 15.7 & \\
\hline \multicolumn{4}{|c|}{ Sex } \\
\hline Male & 137 & 53.7 & \\
\hline Female & 118 & 46.3 & \\
\hline \multicolumn{4}{|c|}{ Marital status } \\
\hline Single & 75 & 29.4 & \\
\hline Married & 165 & 65.5 & \\
\hline Separated & 13 & 5.1 & \\
\hline \multicolumn{4}{|c|}{ Religion } \\
\hline Islam & 57 & 22.4 & \\
\hline Christianity & 197 & 77.7 & \\
\hline \multicolumn{4}{|c|}{ Academic qualification } \\
\hline $\mathrm{OND} / \mathrm{NCE}$ & 52 & 20.4 & \\
\hline HND/B.Sc. & 152 & 59.6 & \\
\hline M.S.c/PhD & 51 & 20.0 & \\
\hline \multicolumn{4}{|c|}{ Years of working experience } \\
\hline$<5$ years & 94 & 36.9 & \\
\hline $6-10$ years & 112 & 43.9 & 8.05 years \\
\hline$>10$ years & 49 & 19.2 & \\
\hline \multicolumn{4}{|c|}{ Monthly income } \\
\hline$<50,000$ & 35 & 13.7 & \\
\hline $51,000-100,000$ & 113 & 44.3 & $104,481.2$ \\
\hline$>100,000$ & 107 & 42.0 & \\
\hline
\end{tabular}

Source: Field Survey, 2018

reported that most agricultural employees in the South Western part of Nigeria were in the age range of 30-40 years. Also, results revealed that majority (53.7\%) of the respondents were male while, $46.3 \%$ were female indicating that male staff were more than female staff in the study area. This results corresponds with the observation of Banmeke (2010); Nwokocha (2011); Julie (2013); that men are more employed than women in almost every organization in Nigeria. It is worthy to note that, more than half $(77.7 \%)$ of the employees were Christians while, $22.4 \%$ were Muslims. This also shows that Christianity is the dominant religion in the South Western part of Nigeria (Ajayi, 2013). The study also revealed that, almost majority (65.5\%) of the respondents were married. The result is in line with the study of Banmeke and Oose (2012) who reported that there were more married people in research institutes in the Southwest Nigeria and this was as a result of influence of tradition that encourage matured people to get married in this part of the world. This was further confirmed by the report of Eze (2010) and Fapojuwo (2010); Banmeke and Oose (2012) who asserted that marriage confers some level of responsibility and commitment on the individual.

\section{Workplace Deviance Behaviour Indicators in the Study Area}

Various forms of workplace deviance were explored during the course of study. Major workplace deviances identified were: divulgence of confidential company information with an unauthorized person $(\bar{x}=3.24)$, falsification of receipt $(\bar{x}=3.32)$ and taken of organizational property without permission $(\bar{x}=3.06)$. The implication of this results is that, involvement of employees in any forms of deviant behavior will reduce performance flow. This results is supported by Robinson and Bennett (1995) who said that deviant behaviours, such as sabotage, theft, harassment, incivility, and work-slowing habit not only account for losses of the organization but also they do shatter organizational image. Also, refusal of boss instruction $(\bar{x}=2.90)$, this results is supported by Galperin (2002); Pituch and Steves (2016) who said that most of the employees disobeyed manager's advice or overlooked order.

More so, others deviant behaviour were laziness at work $(\bar{x}=2.89)$, use of illegal drug/consumed alcohol on the job $(\bar{x}=2.88)$, invasion of government property without permission $(\bar{x}=2.81)$, rudely manner of approach $(\bar{x}=2.79)$. Some of these major deviant behavior will affect some committed and loyal staff as it may affect overall productivity of the organization. This results is supported by Hershcovis et al. (2007); Abiona (2015); Ng (2017) who were of the opinion that most employees are very aggressive at work and also indulging in various sharp practices.

In addition, most employees always play prank at work $(\bar{x}=2.71)$ which make other loss temper with colleagues $(\bar{x}=2.61)$. This results implies that leaking or releasing organizational information to unauthorized persons may cause conflict that may not be handled by the management of an institution and which deprive the attainment of organizational goals. It is worthy to note that, some of this vital document are meant for official use, if such information gets out it may create a bad image for the organization. Also, many employees had the habit of cheating the Government through falsification of receipts which has become major norm in most government owned institutions in developing counties. Fortification of management receipt may cause the organization extra cost and 
II: Distribution of various forms of workplace deviance behaviour

\begin{tabular}{|c|c|c|}
\hline Variables & MEAN & S.D \\
\hline \multicolumn{3}{|l|}{ Production Deviance } \\
\hline I put in little effort at work & 2.89 & 1.42 \\
\hline I have left work early without permission from my boss & 2.81 & 1.55 \\
\hline I intentionally work slower than I could have worked & 2.78 & 1.45 \\
\hline I spend too much time fantasizing or day dreaming instead of working & 2.58 & 1.36 \\
\hline I come in late to work without permission & 2.50 & 1.41 \\
\hline I have left work for someone else to finish the job & 2.50 & 1.52 \\
\hline I have worked on a personal matter instead of work for my employer & 2.39 & 1.21 \\
\hline I have taken an additional or a longer break than is acceptable any at your workplace & 2.27 & 1.45 \\
\hline I have dragged out work in order to get overtime pay & 1.89 & 1.23 \\
\hline \multicolumn{3}{|l|}{ Property Deviance } \\
\hline I have falsified receipt to get reimbursed for more money than you spent on business expenses & 3.32 & 1.54 \\
\hline I litter my work environment & 3.06 & 1.47 \\
\hline I have taken a property from work without permission & 3.06 & 1.50 \\
\hline \multicolumn{3}{|l|}{$\begin{array}{l}\text { Political Deviance } \\
\end{array}$} \\
\hline I discuss confidential company information with an unauthorized person & 3.24 & 1.43 \\
\hline I always communicate in a lousy manner in my place of work & 3.01 & 1.56 \\
\hline I hardly follow my boss's instruction & 2.90 & 1.48 \\
\hline \multicolumn{3}{|l|}{ Personal Aggression } \\
\hline I use an illegal drug or consumed alcohol on the job & 2.88 & 1.53 \\
\hline I do embarrass people publicly at work & 2.25 & 1.47 \\
\hline I do play mean pranks on people at work & 2.71 & 1.33 \\
\hline I act rudely to people at work & 2.79 & 2.38 \\
\hline I have made fun of someone at work & 2.15 & 1.23 \\
\hline I have lost my temper at work & 2.61 & 2.36 \\
\hline I have said something harmful to someone at work & 2.46 & 1.43 \\
\hline I make an ethnic, religious, or racial remarks or jokes at work & 2.41 & 1.34 \\
\hline I have cursed someone at work & 2.81 & 1.43 \\
\hline
\end{tabular}

Source: Field survey, 2018

this may affect other things within the organization. Other forms of deviance identified were too much fantasizing at work $(\bar{x}=2.58)$ and most came late to work without permission.

\section{Level of Employees' Job Performance}

Job performance is the relative contribution of individual to their organization that is it the output of an individual effort in relation to the pre-decided target (Kart et al., 2018; Abiona et al., 2019). Based on this premises, the contributions of the employees in term of job performance was examined. Major performance indicators identified were: training on the job improve the employees' competencies $(\bar{x}=4.11)$. This results agreed with the assertion of Hair et al. (2014); Abiona et al. (2015); Soleimani et al.
(2017) who opined that most of the deviant behavior of the staff will reduce if they have undergone training programmes. Also, other performance indicators that reduce deviant behavior among the employees were: conducive working condition $(\bar{x}=4.08)$, availability of instructions and resources for task at hand $(\bar{x}=4.05)$. This study implies that, if the organizational climate is conducive, the rate at which employees will perform will be high.it could be said that, conducive environment can abate the workplace deviant behavior of employees and tends to enhance the performance of employees (Uddin et al., 2013).

Other performance indicators were: differences in performance of employee when tasked with the same objective $(\bar{x}=3.99)$, usage of evaluation 
III: Distribution of the respondent's level of employees' job performance

\begin{tabular}{|c|c|c|}
\hline Variables & Mean & S.D \\
\hline Training on the Job helped me improve competence in my specialization & 4.11 & 1.34 \\
\hline $\begin{array}{l}\text { Explicit instructions and resources needed for a particular objective are given by management before } \\
\text { execution }\end{array}$ & 4.05 & 1.41 \\
\hline $\begin{array}{l}\text { Organizational management ensures there is a performance and evaluation process to evaluate workers } \\
\text { competence }\end{array}$ & 3.96 & 1.34 \\
\hline Presence of working tools influence my faithfulness to standard operating procedures & 3.95 & 1.42 \\
\hline Sufficient time is given to me by the management to ensure the proper execution of an objective. & 3.89 & 1.21 \\
\hline
\end{tabular}

Source: Field survey, 2018

IV: Level of employee's job performance

\begin{tabular}{ccc}
\hline Level & Frequency & Percentage \\
\hline High (23-45) & 132 & 51.9 \\
Low (9-22.5) & 123 & 48.1 \\
\hline
\end{tabular}

Source: Field survey, 2018

forms $(\bar{x}=3.96)$, availability of working tools $(\bar{x}=3.95)$, sufficient time attached to execution of job $(\bar{x}=3.89)$, privacy in workplace influences job effectiveness $(\bar{x}=3.56)$ which increase the quality of work $(\bar{x}=2.89)$. This finding agrees with Wright and Geroy (2001) who opined that employee's competencies change through effective training programs, which improves the overall job performance of the employees. This is, if there is enough interaction with time, working facilities and conducive environment in an organization will not only boost but also will increase rate at which employee discharge their duties and obligation and nail deviant behavior to minimal degree (Sun and Wang, 2017; Turkey et al., 2017). It is worthy to note that, employees had high or moderate level $(51.9 \%)$ of job performance despite various forms of deviant behavior identified in the studied institutions. This results agree with the opinion of Green et al. (2013) who said that high performance will decrease deviant behavior at workplace and thereby increases their intention to contribute to organizational goals.

\section{Test of Relationship Between Workplace Deviance and Employees' Job Performance}

The results of regression analysis of the relationship between workplace deviant behavior and employee's job performance is shown in Tab. V. The model produced a good fit for the data as evidence by statistical significance at $(p<0.01)$ and the adjusted $R^{2}$ of 0.338 which implies that the explanatory variables is $51.9 \%$ explained in the dependent variable. Also, inclusion of job performance variables in the model as an explanatory variable is also justified by the statistical significance of rho $(P<0.05)$. This implies that estimation of the model as regression would have yielded inefficient parameters.

Therefore, the results of the model of workplace deviance decreases the rate at which employees performed at work $(P<0.05)$. This implies that employees that deviate the rule and regulations of an organization will definitely perform poor at work since most organization are looking for more committed, loyal and competent employee. This

V: Workplace deviance indicators and employee's job performance

\begin{tabular}{lrrc}
\hline \multicolumn{1}{c}{ Variables } & Coefficient & $\begin{array}{c}\text { Standard } \\
\text { Error }\end{array}$ & \multicolumn{1}{c}{ Tsat } \\
\hline (Constant) & 7.479 & & 2.110 \\
Age & .260 & .182 & .775 \\
Sex & 1.065 & -.009 & -.149 \\
Religion & 1.239 & -.121 & $-2.154^{* *}$ \\
Marital status & 1.213 & .004 & .061 \\
Academic qualification & .912 & -.168 & $-2.601^{* * *}$ \\
Years & .195 & -.622 & $-5.429^{* * *}$ \\
Monthly income & .000 & -.014 & -.165 \\
Political deviance & .050 & .085 & $1.682^{*}$ \\
Property deviance & 1.296 & .295 & $2.968^{* * *}$ \\
Production deviance & 1.270 & -.099 & $-1.709^{*}$ \\
Personal deviance & 1.476 & .343 & $2.794^{* * *}$ \\
\hline$R^{2}=0.338$ & & & \\
$R=0.58$ & & & \\
Fratio = 5.087 & & & \\
\hline Source: Fidd & & & \\
\hline
\end{tabular}

Source: Field survey, 2018 
results is supported by Johns (2001) who asserted that any forms of deviance at workplace will lead to low productivity and poor job performance. Dunlop and Lee (2004); Appelbaum et al. (2007) Rahim and Cosby (2016); Olsen et al. (2017), to the fact that the employees' workplace incivility such as aggression, intentional slowing down of the work, keeping busy with non-scheduled task, passing idle time, gossiping with peers, and so forth, contributes to the bottleneck and ineffectiveness in the organizational performance which can result into a total damage of the organization. This results also affirmed the thought of Uddin et al. (2013); Rahim and Cosby (2016); Wu et al. (2017); Abiona et al. (2019); Blickle and Schütte (2017); Zheng et al. (2017) that is deviant behavior are beyond the acceptable norms of any organization which may bring huge negative impact on the productivity and deterioration of overall performance.

Also, the results revealed that religion is negatively significant $(p<0.05)$ to employee's job performance. It implies that despite employee's belief in one religion or the other, involving in one form of deviant behavior reduces performance rate. It shows that as belief of the employees increases the rate at which employees perform at work decreases. This implies that better performance cannot be attached to religion of the respondents as observed in the descriptive statistic on personal profile that reveals that $77.7 \%$ of the respondents were Christian. This results is in line with the assertion of Abiona et al. (2018) who assert that employee's belief has nothing to do with the way and manners they perform at work. More so, the educational level of the respondents is statistically significant at $(P<0.01)$ to their job performance, this results implies that being educated decrease employees deviant behavior and increase the rate at which employees perform at work especially those employees with higher educational certificate, therefore acquisition of higher certificate could reduce deviant behavior in profit driven organization. The years of experience of the respondents is positively statistical significant at $(P<0.01)$. This results implies that as employees grows with the culture, norms and values of an organization, it could be said that most of them would have gathered much experiences that could serve as checker to most workplace deviant behavior for better job performance (Hair et al., 2014; Aksu, 2016; Adeogun et al., 2019).

Furthermore, the twenty four items used to measure workplace deviance (WD) was further recategories into four such as production and political deviance which was minor type and property and personal deviance which happen to be the major type of workplace deviance. Regression analysis shows that property deviance is positively significant at $(p<0.1)$. This results implies that, various sharp practice that has become part of employees norm will affect other aspect of the job and reduce employee's job performance. Personal deviance is positively significant at $(p<0.0)$, personal trait such as anger, bitterness uses of hard drug and grudges will reduce staff performance at work. It is worthy to note that, the whole world had gone political therefore, political deviance is significant at $(p<0.10)$ to job performance in the studied organization. The implication of this results is that, most of the employee's engaged in politics and also use politic as cover-up to abscond from duties. This had been a treat to work and also discourage most committed employee in discharging their responsibility. This results corroborated the assertion of Porath and Pearson (2013); Souto (2015); Zheng et al. (2017) also said that workplace deviant behavior has a negative influence on job performance. More so, production deviance is positively significant at $(p<0.10)$ to employee's job performance. This implies that employee whose roles is not well defined may involves in any form of workplace deviance such as organizational politics and lack of job description. This results is in line with the assertion of Robinson and Bennett (1995); Uddin et al. (2013); Islam (2014); Kenbock and Boehm, 2015; Darvishmotevali et al. (2017) who was of the opinion that, employees whose roles is not well defined will engage in gossiping, blaming coworker for their negligence and misfortunes.

\section{CONCLUSION}

The present study showed that employee's job performance is highly related to property, production, political and personal deviant behavior. That is, most of the employees engaged in one form of workplace deviance behavior such as aggression, intentional slowing down of the work, keeping busy with non-scheduled task, passing idle time and gossiping with peers are affected job performance in the three locations used in this study. The study also concluded that most employees were found in the habit of taking government property without permission and this property deviance had jeopardize most of the activities in profit-driven organization. Also, it was found that most of the staff that were subjected to training were not engage in most of the identified workplace deviant practices. The significance of conducive environment as job performance enhancer had yielded a positive results in terms of managing most of the workplace deviant behavior in the study area. More so, this study also found that in order to increase employees' job performance, the management must put measure in place to tame workplace deviant behavior in the study area. Based on this, the following 
recommendations were made as a preventive measures against workplace deviant behaviors and better employee's job performance for attainment of organizational goals. Prominent among these measures include: strong penalty for any form of deviant behavior (either minor or major in the study area), efforts should also be made by the management of the organization to organized short training that will give them better exposure to staff on how to manage organizational properties. Also, the management should create environment conducive for employees to discharge their duties and obligations. If all these recommendations are put in place, it is probable, that employees will have no option than to leave the deviant behavior and contribute to organization goals.

\section{REFERENCES}

ABASSI, S. M. and HOLLMAN, K. W. 2000. Turnover: the red bottom line. Public Personal Management, 2(3): 333-342.

ABIONA, B. G., ALABI, S. O., OLORODE, S. and ADEOTI, T. E. 2020. Effects of organizational culture on employee's job performance in selected agricultural research institute, Oyo State, Nigeria. Journal of agricultural and rural development, 18: 15-27.

ABIONA, B. G., ALIU, O. S., AJIBOYE, M. D. and TONY, A. 2019. Effect of Leadership Competency on Employee's Job Turnover in Ogun-Oshun River Basin Development Authority (OORBDA), Ogun State, Nigeria. Journal of Sustainable Development, 10(1): 123-129.

ABIONA, B. G., ADEOGUN, S. O. and ALADE, M. S. 2017. Influence of work-life conflict on agricultural employee's job performance in forest research institute of Nigeria (frin), Oyo state, Nigeria. Ife Journal of Agriculture, 29(2): 1-9.

ABIONA, B. G., AJAYI, M. T. and FAPOJUWO, O. E. 2014. Influence of managerial behaviour on Agricultural Employees' job Performance. Journal of Extension System, 30(2): 13-25.

ABIONA, B. G. 2015. Effect of communication pattern on Agricultural Employees'. Journal of Extension System, 31(2): 25-35.

ABDULLAH, A. and MARICAN, S. 2017. Relationship between leadership perception and engagement in workplace deviant behavior. The Malaysian Journal of Social Administration, 9(1): 131-150.

ADEOGUN, S. O., ABIONA, B. G., ALABI, S. O. and YILA, J. 2019. Perceived effect of coaching and mentoring on employee job performance among academic staff in university of Ibadan, Oyo State, Nigeria. Journal of Humanities, Social Sciences and Creative Arts, 18(1): 98-110.

AKSU, A. 2016. Organizational deviance and multi-factor leadership. Educational Research and Reviews, 11(8): 589-597.

APPELBAUM, S. H., IACONI, G. D. and MATOUSEK, A. 2007. Positive and negative deviant workplace behaviors: causes, impacts, and solutions. Corporate Governance: The international journal of business in society, 7(5): 586-598.

AREMU, A. O. and ADEYOJU, C. A. 2003. Job Commitment, job satisfaction and gender as predictors of mentoring in Nigeria Police, Policing. An international journal of police strategies and management, 26(3): 377-385.

BANMEKE, T. O. A. 2010. The use of information and communication technologies (ICTs) by agricultural researchers in Edo state, Nigeria. Journal of Development Communication, 21(1): 53-61.

BANMEKE, T. O. A. and OOSE, M. O. 2012. Assessment of Usage of Social Network Tools (SNTs) by Agricultural Researchers in South West Nigeria. Communication of the IIMA, 12(2): 35-50.

BENNETT, R. J. and ROBINSON, S. L. 1995. Development of a measure of workplace deviance. Journal of Applied Psychology, 85(3): 349-360.

BENNETT, R. J. and ROBINSON, S. L. 2003. The past, present and future of workplace deviance research. In: GREENBERG, J. (Ed.). Organizational Behaviour, The State of the Science. $2^{\text {nd }}$ Edition. Mahwah, NJ: Erlbaum.

BLICKLE, G. and SCHÜTTE, N. 2017. Trait psychopathy, task performance, and counterproductive work behavior directed toward the organization. Personality and Individual Differences, 109: 225-231.

BOLIN, A. and HEATHERY, L. 2001. Predictors of employee deviance: The relationship between bad attitudes and bad behavior. Journal of Business and Psychology, 15(3): 405-418.

DARVISHMOTEVALI, M., ARASLI, H. and KILIC, H. 2017. Effect of job insecurity on frontline employee's performance. International Journal of Contemporary Hospitality Management, 29(6): 1724-1744.

DU, Y., ZHANG, L. and CHEN, Y. 2016. From creative process engagement to performance: Bidirectional support. Leadership and Organization Development Journal, 37(7): 966-982.

DUNLOP, P. D. and LEE, K. 2004. Workplace deviance, organizational citizenship behavior, and business unit performance: The bad apples do spoil the whole barrel. Journal of Organizational Behavior, 25(1): 67-80. 
EZE, H. C. 2010. Leadership in Organization. Journal of Nigerian Institute of Management, 46(1): 29-35. FAO. 1997. Review of the state of World Aquaculture. FAO Fisheries Cir. 886 (Rev. 1). FAO.

FAPOJUWO, O. E. 2010. Influence of socio-economic characteristics on use of modern cassava processing technologies among women processor in Ogun State. Journal of Social Science, 24(1): 45-50.

FRIEDMAN, A., CARMELI, A. and DUTTON, J. E. 2018. When does respectful engagement with one's supervisor foster help-seeking behaviors and performance? Journal of Vocational Behavior, 104: 184-198.

GALPERIN, B. L. 2002. Determinants of deviance in the workplace: An empirical examination in Canada and Mexico. Dissertation Tehesis. Montreal: Concordia University.

GREEN, A. E., MILLER, E. A. and AARONS, G. A. 2013. Transformational leadership moderates the relationship between emotional exhaustion and turnover intention among community mental health providers. Community mental Health Journal, 49(4): 373-379.

GRIFFIN, R. W. and LOPEZ, Y. P. 2005. "Bad behavior” in organizations: A review and typology for future research. Journal of Management, 31(6): 988-1005.

ISAAC, B. O. 2011. Information Communication Technology as drivers of growth: experience for selected scale producer in rural south west. Ibadan, Nigeria.

ISLAM, N. 2014. Corruption, Its control and drivers of change: The case of Bangladesh. Dhaka-1207: Bangladesh Institute of development Studies.

HAIR, J. F., HULT, G. T., RINGLE, C. M. and SARSTEDT, M. 2014. A primer on partial least squares structural equation modeling (PLS-SEM). SAGE Publications Inc.

HERSHCOVIS, M. S., TURNER, N., BARLING, J., ARNOLD, K. A., DUPRÉ, K. E., INNESS, M. and SIVANATHAN, N. 2007. Predicting workplace aggression: a meta-analysis. Journal of Applied Psychology, 92(1): 228-238.

JOHNS, G. 2001. The psychology of lateness, absenteeism and turnover. In: ANDERSON, D., ONES, H., SINANGLI, H. K. and VISWESVARIAN, C. (Eds.). Handbook of Industrial, work and Organizational psychology. London Sage, pp. 232-252.

JIANG, H., CHEN, Y., SUN, P. and YANG, J. 2017. The relationship between Authoritarian leadership and employees' deviant workplace behaviors: The mediating effects of psychological contract violation and organizational cynicism. Frontiers in Psychology, 8: 732-712.

JULIE, M. 2013. Women and the workplace. Mediterranean Journal of Social Sciences, 6(2): 118-125.

KARK, R., VAN DIJK, D. and VASHDI, D. R. 2018. Motivated or demotivated to be creative: The role of self-regulatory focus in transformational and transactional leadership processes. Applied Psychology, 67(1): 186-224.

KATOU, A. A. 2015. Transformational leadership and organizational performance. Employee Relations, 37(3): 329-353.

KENSBOCK, J. M. and BOEHM, S. A. 2015. The role of transformational leadership in the mental health and job performance of employees with disabilities. The International Journal of Human Resource Management, 27(14): 1580-1609.

KLINE, R. B. 2011. Principles and Practice of Structural Equation Deviant Workplace Behavior and Job Performance 177 Modeling. New York, NY: The Guilford Press.

KOTTAWATTA, K. 2007. Impact of attitudinal factors on job performance of executives and nonexecutive employees in apparel industry in Sri Lanka. Sri Lankan journal of Human resource management, 1(1): 53-70.

MAZNI, A. and ROZIAH, M. R. 2011. Towards developing a theoretical model on the determinants of workplace deviance among support personnel in the Malaysian Public Service Organizations. In: $12^{\text {th }}$ International Conference on Human Resource Development Research and Practice Across Europe. The University of Gloucestershire, Cheltenham, England.

MEKPOR, B. and DARTEY-BAAH, K. 2017. Leadership styles and employees' voluntary work behaviors in the Ghanaian banking sector. Leadership \& Organization Development Journal, 38(1): 74-88.

NG, T. W. H. 2017. Transformational leadership and performance outcomes: Analyses of multiple mediation pathways. The Leadership Quarterly, 28(3): 385-417.

NWOKOCHA, I. 2011. Sustainable Managerial Strategies for employee Retention in Two Private sector Organizations in Port Harcourt, Rivers State, Nigeria. Unpublished Ph.D Thesis. Ebonyi State University, 2014.

OLSEN, E., BJAALID, G. and MIKKELSEN, A. 2017. Work climate and the mediating role of workplace bullying related to job performance, job satisfaction, and work ability: A study among hospital nurses. Journal of Advanced Nursing, 73(11): 2709-2719.

OGUNYENI, B. 2006. Gender and Behaviour, Gender Socio-economic Status and educational level as Determents of Career maturity of Nigeria Adolescents. Gender and Behaviour, 4(1): 686-700.

PENG, J. C., TSENG, M. M. and LEE, Y. L. 2011. Relationships among supervisor feedback environment, work-related stressors, and employee deviance. Journal of Nursing Research, 19(1): 13-24. 
PITUCH, K. A. and STEVENS, J. P. 2016. Applied multivariate statistics for the social sciences. New York, NY: Routledge, Taylor \& Francis Group.

PORATH, C. and PEARSON, C. 2013. The price of incivility. Harvard Business Review, 91(1-2): 114-121.

RAHIM, M. A. and COSBY, D. M. 2016. A model of workplace incivility, job burnout, turnover intentions, and job performance. Journal of Management Development, 35(10): 1255-1265.

RAHMAN, M. S., FERDAUSY, S. and KARAN, R. 2012. Relationships among emotional intelligence, deviant workplace behavior, and job performance: an empirical study. Portuguese Journal of Management Studies, 17(1): 39-62.

ROBINSON, S. and BENNETT, R. 1995. A typology of deviant workplace behaviours: a multidimensional scaling study. Academy of Management Journal, 38: 555-572.

ROBBINS, S. P., JUDGE, T. A. and SANGHI, S. 2009. Organizational Behavior. Delhi, India: Pearson Prentice Hall.

SHARMA, N., SCHUSTER, P. L.-T., BA, T. and SINGH, V. K. 2016. Effect of workplace incivility on job satisfaction and turnover intentions in India. South Asian Journal of Global Business Research, 5(2): 234-249.

SPECTOR, P. E., FOX, S. and DOMAGALSKI, T. 2006. Emotions, violence and counterproductive work behavior. In: KELLOWAY, E. K., BARLING, J. and HURRELL, J. (Eds.). Handbook of workplace violence. Thousand Oaks, CA: Sage, pp. 29-46.

SCHILPZAND, P., DE PATER, I. E. and EREZ, A. 2016. Workplace incivility: A review of the literature and agenda for future research. Journal of Organizational behavior, 37: S57-S88.

SOLEIMANI, M., DANAEI, H., JOWKAR, A. and PARHIZGAR, M. M. 2017. Factors affecting social commerce and exploring the mediating role of perceived risk (Case Study: Social media users in Isfahan). Iranian Journal of Management Studies, 10(1): 63-90.

SOUTO, J. E. 2015. Business model innovation and business concept innovation as the context of incremental innovation and radical innovation. Tourism Management, 51: 142-155.

SUN, R. and WANG, W. 2017. Transformational leadership, employee turnover intention, and actual voluntary turnover in public organizations. Public Management Review, 19(8): 1124-1141.

TSUI, A. S., PEARCE, J. L., PORTER, L. W. and TRIPOLI, A. M. 1997. Alternative approaches to the employee-organization relationship: Does investment in employees pay off? Academy of Management Journal, 40(5): 1089-1121.

TURKEY, M. R., LI, Y. and CHEN, P. Y. 2017. The role of transformational leadership in workplace bullying. Journal of Organizational Effectiveness: People and Performance, 4(3): 199-217.

UDDIN, M. A., FAN, L. and DAS, A. K. 2017. A study of the impact of transformational leadership, organizational learning, and knowledge management on organizational innovation. Management Dynamics, 16(2): 42-54.

UDDIN, M. A., RAHMAN, M. S. and HOWLADAR, M. H. R. 2013. Exploring the relationship among transformational leadership, deviant workplace behaviour, and job performance: An empirical study. In: Proceedings from the South Asian Management Forum, India.

WRIGHT, P. and GEROY, D. G. 2001. Changing the mindset: the training myth and the need for worldclass performance. International Journal of Human Resource Management, 12(4): 586-600.

ZHENG, W., WU, Y. C. J., CHEN, X. and LIN, S. J. 2017. Why do employees have counterproductive work behavior? The role of founder's Machiavellianism and the corporate culture in China. Management Decision, 55(3): 563-578.

Contact information

Bolaji Grace Abiona: dolace6ng@gmail.com

Dele Akin Adesanya: deleadesanya1@gmail.com

Samuel Temitope Oyekanmi: temitopeoyekanmi@gmail.com

Micheal Tunde Ajayi: ajayimt@funaab.ed.ng 
